\title{
Response of Pea (Pisum sativum) to Sugar Industry Effluent Treatment
}

Kamlesh

\author{
Department of Energy \& Environmental Sciences, Chaudhary Devi Lal University, Sirsa, India
}

\begin{abstract}
Sugar mills play a major role in polluting the soil and water bodies by discharging a large amount of waste water as effluent. The present research work has been carried out to assess the impact of sugar mill effluent applied in different dilutions i.e 25\%, 50\%, 75\% and 100\% along with control on pea (Pisum sativum) seeds to investigate their effect on seed germination and growth parameters such as germination percentage, shoot length, root length, seedling vigour, plant fresh weight and dry weight by pot culture. The low effluent $\mathrm{pH}$ (4.3), Total dissolved solids (TDS, $1990 \mathrm{mg} / \mathrm{L}$ ), Biochemical oxygen demand $(B O D, 850 \mathrm{mg} / \mathrm{L})$ and Chemical oxygen demand (COD, $2920 \mathrm{mg} / \mathrm{L}$ ) indicated the high inorganic and organic content with an acidic load. The present study was carried out with the aim that sugar mill effluent shows positive or negative effect on plant growth. The result indicated that sugar mill effluent did not show any inhibitory effect on germination percentages and germination values at lower concentration in the seeds tested.
\end{abstract}

Keywords-Sugar mill effluent, Pisum sativum, seed germination, seedling vigour.

\section{INTRODUCTION}

Industrial activities generate a wide variety of waste effluents which are generally discharged into water courses. Among the effluent discharging industries such as fertilizer, pulp and paper, textile, sugar mills, tanneries, distilleries etc, sugar mills play a major role in polluting the water bodies because it contains large quantities of chemical elements. India is the second largest producer of sugar in the world after Brazil with 550 sugar mills and 220 million tons cane per year and total sugar production 13.5 million tons per year (Kaur et al., 2010). Sugar industry effluent contains several organic and inorganic contents in different concentrations. The effluents also alter the physicochemical characteristics, and flora and fauna of receiving water bodies. Use of sugar mill effluents for agricultural purposes is a highly warranted utility of water pollutants proposition. The continuous use of such type of effluents harmfully affects the crops when used for irrigation. The effluent not only affects the plant growth but also deteriorate the soil properties when used for irrigation (Maliwal et al., 2004).

Use of industrial waste water for irrigation purposes has emerged an important way to utilize its nutrients and removal of its pollution load by growing tolerant plant species. Efforts have been made by different workers to determine the effect of sugar mill effluent on seed germination of various crops such as paddy (Samuel and Muthukkaruppan, 2011), Vigna angularis, Vigna cylindrical and Sorghum cernum (Doke et al., 2011), Brassica campestris (Beg et al., 2010), wheat, barley, pea, black gram and mustard (Nath $\boldsymbol{e t}$ al., 2007), rice (Rath $\boldsymbol{e t}$ al., 2013), fenugreek (Kamlesh and Kidwai, 2016), Black gram (Vaithiyanathan et al., 2014; Elayaraj, 2014), cow pea (Mycin, 2014) and Raphanus sativus (Vijayaragavan et al., 2011). Plant responses to sugar mill effluent has been studied and reviewed extensively by (Vaithinathan $\boldsymbol{e t}$ al., 2014; Elayaraj 2014; Kamlesh, 2016).

The present study was conducted to evaluate the impact of different concentrations of sugar mill effluent on seed germination and other growth parameters of Pea (Pisum sativum).

\section{MATERIALS AND METHODS}

An effluent sample was collected from the outlet of the sugar mill situated at Bhali, Rohtak (Haryana co-op. sugar mills ltd), Haryana, India during the month of November. Effluent sample was collected in precleaned, sterilized plastic container and were stored at $4^{\circ} \mathrm{C}$ for physicochemical analysis. The methodology of APHA (2010) was followed for physico-chemical analysis of the collected effluent. The seeds of pea (Pisum sativum) were procured from certified local supplier and were surface sterilized by following the method of Aery (2010) prior to germination studies. Different concentrations of effluent $(25 \%, 50 \%$, $75 \%$ and $100 \%$ ) were prepared by using distilled water along with control in triplicate. Ten healthy seeds were sowed in each pot of different concentrations to study the response of test plant. Germination percentage was recorded 
after 7 days. Growth of the root and shoot length were measured after 14 days with the help of meter scale. Fresh and dry weight of test plants was determined on a digital balance.

Statistical analysis was done by using SPSS software ver. 20. Data were analyzed for mean, standard deviation and one way analysis of variance. ANOVA is used to compare these data between treated seedlings and control seedlings. $P$ values less than 0.05 was considered to be significant.

Table.1: Physico-chemical analysis of effluent

\begin{tabular}{|c|c|c|}
\hline S.No. & Parameters & Sugar Effluent \\
\hline 1 & Colour & Dark brown \\
\hline 2 & Odour & Decaying smell \\
\hline 3 & $\mathrm{pH}$ & 4.3 \\
\hline 4 & Temperature & $34^{\circ} \mathrm{C}$ \\
\hline 5 & EC $(\mu \mathrm{S})$ & 3.2 \\
\hline 6 & TS $(\mathrm{mg} / \mathrm{l})$ & 2400 \\
\hline 7 & TDS $(\mathrm{mg} / \mathrm{l})$ & 1990 \\
\hline 8 & TSS $(\mathrm{mg} / \mathrm{l})$ & 410 \\
\hline 9 & COD $(\mathrm{mg} / \mathrm{l})$ & 2920 \\
\hline 10 & BOD $(\mathrm{mg} / \mathrm{l})$ & 850 \\
\hline 11 & Total hardness $(\mathrm{mg} / \mathrm{l})$ & 210 \\
\hline 12 & Total alkalinity $(\mathrm{mg} / \mathrm{l})$ & 320 \\
\hline 13 & Chloride $(\mathrm{mg} / \mathrm{l})$ & 190 \\
\hline
\end{tabular}

III. RESULTS AND DISCUSSION

The physico-chemical analysis of sugar mill effluent is given in Table-1.

The characterization of the effluent revealed that it is dark brown in colour which could be due to presence of melanoidin which is the product of sugar amine condensation and decaying smell due to presence of indole and sulphure compounds (Rath et al., 2010). According to previous studies $\mathrm{pH}$ plays a significant role in toxicity (Truman et. al., 1986, Martin, 1987). The $\mathrm{pH}$ of the effluent was found acidic in nature having $\mathrm{pH}$ of 4.3. The acidic nature of sugar effluent might be due to the use of sulphuric acid and phosphoric acid during sugarcane juice clarification (Memon et al., 2006, Ayyasamy et al., 2008). The value of total solids, total dissolved solids and total suspended solids were $2400 \mathrm{mg} / \mathrm{l}, 1990 \mathrm{mg} / \mathrm{l}$ and $410 \mathrm{mg} / \mathrm{l}$ respectively. The effluent had higher BOD, $850 \mathrm{Mg} / \mathrm{l}$ and COD, $2920 \mathrm{mg} / \mathrm{l}$. The higher concentration of BOD and COD indicated the higher concentration of organic and inorganic substances in the effluent. Further the values of total hardness $(\mathrm{TH})$, total alkalinity (TA) and chloride were $210 \mathrm{mg} / \mathrm{l}, 320 \mathrm{mg} / \mathrm{l}$ and $190 \mathrm{mg} / \mathrm{l}$ respectively. The presence of high amount of COD, BOD, suspended solids, total hardness were also recorded by Baruah et al., 1996; Medhi et al., 2008.

The observation made on the effect of sugar mill effluent on growth parameters of pea (Pisum sativum) are presented in Tables (2-7). The results clearly indicate that at lower concentrations test plant responded in a better way in comparison of control showing the supply of essential nutrients needed for plant growth and metabolism. The higher concentration of effluent decreased the germination studies parameters. Similar observations were obtained by Singh and Mishra (1987), Verma and Verma (1995), Lakshmi and Sundaramoorthy (2000), Rajesh et al., (2013) and Vaithiyanathan et al., (2014) while studying the effect of various industrial effluent on some agricultural crops. The increase in germination study parameters at lower concentration may be due to presence of growth promoting nature of nutrients present in the diluted effluent (Sahai et al., 1979). The reduction in growth parameters at higher concentrations of effluent may be due to the presence of excess amount of elements present in the effluent which inhibit the seed germination and growth by interfering the metabolic activities (Biradar et al., 1989; Srivastava et al., 1988; Verma and Verma, 1995; Kaushik et al., 2004).

Table.2: Effect of different concentrations of effluent on germination percentages

\begin{tabular}{|c|c|c|c|}
\hline S. & $\begin{array}{c}\text { Concentration } \\
\mathbf{( \% )}\end{array}$ & $\begin{array}{c}\text { Germination } \\
\mathbf{( \% )}\end{array}$ & $\begin{array}{c}\text { Reduction } \\
\text { /Increase } \\
\mathbf{( \% )}\end{array}$ \\
\hline 1 & Control & $56.7 \pm 5.77$ & - \\
\hline 2 & 25 & $70 \pm 10.00$ & 23.45 \\
\hline 3 & 50 & $76.7 \pm 5.77 *$ & 35.27 \\
\hline 4 & 75 & $53.3 \pm 5.77$ & -6.0 \\
\hline 5 & 100 & $43.3 \pm 5.77$ & -23.63 \\
\hline
\end{tabular}

* Indicates- significant

Table.3: Effect of different concentrations of effluent on seedling vigour

\begin{tabular}{|c|c|c|c|}
\hline $\begin{array}{c}\text { S. } \\
\text { No. }\end{array}$ & $\begin{array}{c}\text { Concentration } \\
(\boldsymbol{\%})\end{array}$ & Vigour & $\begin{array}{c}\text { Reduction } \\
\text { /ncrease } \\
(\boldsymbol{\%})\end{array}$ \\
\hline 1 & Control & $1338.3 \pm 323.8$ & - \\
\hline 2 & 25 & $1401.3 \pm 191.5$ & 4.71 \\
\hline 3 & 50 & $1667.7 \pm 72.6$ & 24.61 \\
\hline 4 & 75 & $952.6 \pm 47.9$ & -28.82 \\
\hline 5 & 100 & $678.3 \pm 31.9^{*}$ & -49.32 \\
\hline
\end{tabular}

* Indicates- significant 
Table.4: Effect of different concentrations of effluent on shoot length $(\mathrm{cm})$

\begin{tabular}{|c|c|c|c|}
\hline $\begin{array}{c}\text { S. } \\
\text { No. }\end{array}$ & $\begin{array}{c}\text { Concentration } \\
(\boldsymbol{\%})\end{array}$ & $\begin{array}{c}\text { Shoot } \\
\text { length }\end{array}$ & $\begin{array}{c}\text { Reduction } \\
(\boldsymbol{\%})\end{array}$ \\
\hline 1 & Control & $10.2 \pm 0.20^{*}$ & - \\
\hline 2 & 25 & $9.3 \pm 0.15^{*}$ & 8.82 \\
\hline 3 & 50 & $9.6 \pm 0.26^{*}$ & 5.88 \\
\hline 4 & 75 & $7.8 \pm 0.10^{*}$ & 23.53 \\
\hline 5 & 100 & $7.3 \pm 0.11^{*}$ & 28.43 \\
\hline
\end{tabular}

* Indicates- significant

Table.5: Effect of different concentrations of effluent on root length $(\mathrm{cm})$

\begin{tabular}{|c|c|c|c|}
\hline $\begin{array}{c}\text { S. } \\
\text { No. }\end{array}$ & $\begin{array}{c}\text { Concentration } \\
(\boldsymbol{\%})\end{array}$ & $\begin{array}{c}\text { Root } \\
\text { length }\end{array}$ & $\begin{array}{c}\text { Reduction } \\
\text { /Increase } \\
(\boldsymbol{\%})\end{array}$ \\
\hline 1 & Control & $10.9 \pm 0.06$ & - \\
\hline 2 & 25 & $10.7 \pm 0.10$ & -1.83 \\
\hline 3 & 50 & $11.5 \pm 0.23^{*}$ & 5.50 \\
\hline 4 & 75 & $10.8 \pm 0.15$ & -0.92 \\
\hline 5 & 100 & $9.2 \pm 0.06^{*}$ & -15.6 \\
\hline
\end{tabular}

* Indicates- significant

Table.6: Effect of different concentrations of effluent on fresh weight ( $\mathrm{mg}$ )

\begin{tabular}{|c|c|c|c|}
\hline $\begin{array}{c}\text { S. } \\
\text { No. }\end{array}$ & $\begin{array}{c}\text { Concentration } \\
(\boldsymbol{\%})\end{array}$ & $\begin{array}{c}\text { Fresh } \\
\text { weight }\end{array}$ & $\begin{array}{c}\text { Reduction } \\
\text { /Increase } \\
(\boldsymbol{\%})\end{array}$ \\
\hline 1 & Control & $0.21 \pm 0.01$ & - \\
\hline 2 & 25 & $0.23 \pm 0.01$ & 9.52 \\
\hline 3 & 50 & $0.18 \pm 0.01$ & -14.28 \\
\hline 4 & 75 & $0.14 \pm 0.02^{*}$ & -33.33 \\
\hline 5 & 100 & $0.11 \pm 0.00^{*}$ & -47.62 \\
\hline
\end{tabular}

* Indicates- significant

Table.7: Effect of different concentrations of effluent on dry weight $(\mathrm{mg})$

\begin{tabular}{|l|c|c|c|}
\hline $\begin{array}{c}\text { S. } \\
\text { vo. }\end{array}$ & $\begin{array}{c}\text { oncentration } \\
(\%)\end{array}$ & Dry weight & $\begin{array}{c}\text { Reduction } \\
\text { /Increase } \\
(\%)\end{array}$ \\
\hline 1 & Control & $0.05 \pm 0.01^{*}$ & - \\
\hline 2 & 25 & $0.07 \pm 0.00$ & 40 \\
\hline 3 & 50 & $0.03 \pm 0.01$ & -40 \\
\hline 4 & 75 & $0.02 \pm 0.00^{*}$ & -60 \\
\hline 5 & 100 & $0.01 \pm 0.00^{*}$ & -80 \\
\hline
\end{tabular}

* Indicates- significant

\section{CONCLUSION}

In the present study sugar mill effluent was studied to know its effect on initial growth parameters such as germination percentage, seedling vigour, shoot length, root length, fresh and dry weight of pea (Pisum sativum). From the present work, it is concluded that lower concentration (25\%-50\%) of sugar mill effluent promoted the growth while higher concentration inhibited the seedling growth.

\section{REFERENCES}

[1] Aery, N.C. (2010). Manual of Environmental Analysis. Anne Books pvt.Ltd.

[2] American Public Health Association (2010).Standard methods for examination of water and waste water, APHA, Washington, DC.pp17.

[3] Ayyasamy P. M., R. Yasodha, S. Rajakumar, P. Lakshmanaperumalsamy, P.K.S.M. Rahman, S. Lee., (2008). Bulletin of Environment Contamination and Toxicology 81,449-454.

[4] Baruah, B.K., Baruah, D. and Das, M. (1996). Study on the effect of paper mill effluent on the water quality of receiving wetland. Poll. Res. 15(4), 389-393.

[5] Beg, M.Z., Kumar, J. and Khan, A.J. (2010). A study on the effect of sugar industry effluent on Brassica campestris L.var. Varuna type-59. Indian J. Sci. Res. 1(1), 31-37.

[6] Biradar, B.B., Mahadevappa, M. and Shrinivasamurthy, C.A., (1989). Influence of industrial effluent on seed germination and seedling growth of some selected plants. Progress in Pollution Research. Pro. Nat. Young Scientists. Seminar Environ. Pollut. University of Agricultural Science, Bangalore, 85-89.

[7] Doke, K.M., Ejazuddin, M. K, Joseph, R., Asif, S. (2011). Physico-chemical analysis of sugar industry effluent and its effect on seed germination of vigna angularis, vigna cylindrical and sorghum cernum. Annuls of Env. Sc., vol.5, 7-11.

[8] Elayaraj, B. (2014). Physico-chemical analysis of sugar factory effluent stress on seedling growth of black gram (Vignamungo (L.)Hepper ) varieties. International Letters of Natural Sciences. ISSN 23009675.12(1)85-93.

[9] Kamlesh, (2016). A review on soil irrigation effect of sugar mill effluent on seed germination. International Journal of Environment, Agriculture and Biotechnology (IJEAB), 1(4), ISSN: 2456-1878., 868872.

[10] Kamlesh, and Kidwai, M.K. (2016). Effect of sugar mill effluent on response of Fenugreek (Trigonella foenum-graecum) varieties. International Journal of Environment, Agriculture and Biotechnology (IJEAB), 1(4), ISSN: 2456-1878.,. 1(4), 844-852. 
[11] Kaur, A., Vats, S., Rekhi, S., Bhardwaj, A., Goel, J., Tanwar, R.S. and Gaur, K.K. (2010). Physicochemical analysis of the industrial effluents and their impact on the soil microflora. Procedia Environmental Sciences, 595-599.

[12] Kaushik, P., Garg, V. K. and Bhupinder, S., (2004). Effect of textile effluents on growth performance of wheat cultivars. Bioresource Technology, 96, 11891193.

[13] Lakshmi, S. and Sundaramoorthy, P. (2000). Effect of sugar mill effluent on germination, seedling growth and biochemical changes in ragi (Elusine corocana Gaertn). Indian J. Environ. Ecoplan., 3(3): 501-506.

[14] Maliwal, G.L., Patel, K.P. and Patel, M.N. (2004). Pollution Resident.231-269.

[15] Martin, R.B. (1987). Transferin binding of Aluminium and iron. Clinical Chem. 33: 405- 407.

[16] Medhi, U.J., Talukdar, A.K. and Deka, S. (2008). Effect of pulp and paper mill effluent on seed germination and seedling growth of Mustard (Brassica campestris), Pea (Pisumsativam) and Rice (Oryzasatival) seeds. Poll Res. 27(3): 437-442.

[17] Memon A. R., S. A. Soomro, A. K. Ansari (2006) J. App. Env. Sci. 1, 152-157.

[18] Mycin, T.R. (2014). Use of sugar mill effluent for irrigation: An evaluative study on the response of germination and growth of cow pea Vigna unguiculata (L.) Walp. Asia Pacific Journal of Research. 1(XVIV), 44-55.

[19] Nath, K., Dharam, S. and Yogesh, K. S. (2007). Combinational effects of distillery and sugar factory effluents in crop plants. J. of Env. Biol. 28(3),577-582.

[20] Rajesh, M., Jayakumar, K., Sathees Kannan, T.M. and Sankar Ganesh, K. (2013). Influence of sugar mill effluent on seed germination and seedling growth of Cluster Bean (Cyamopsis tetragonaloba). International J. Environ. And Bioenergy, 7(2): 54-62.

[21] Rath, P., Biswal, P.K. and Misra, M.K. (2013). Effect of sugar factory distillery spent wash on germination and seedling growth of rice (Oryza sativa L). IJSID.ISSN:2249-5347, 3(1),191-201.

[22] Rath P., G. Pradhan, M. K. Mishra (2010). Journal of Phytology 2(5), 33-39.

[23] Samuel, S. and Muthukkaruppan, S.M. (2011).Physico-chemical analysis of sugar mill effluent, contaminated soil and its effect on seed germination of paddy (Oryza sativa L.).International journal of pharmaceutical and biological archives ; 2(5): 1469-1472.
[24] Sahai, R., Agarwal, N. and Khosla, N. (1979). Effect of fertilizer factory effluent on seed germination, seedling growth and chlorophyll content of Phaseolus Linn. Trop. Ecol., 20(2): 155-165.

[25] Srivastava N., Neelum and Sahai, R. (1988). Ecophysiological response of certain crop plants of Eastern Uttar Pradesh to industrial effluents. Int. J. Ecol. Environ. Sci., 14: 229-248.

[26] Singh, K.K. and Mishra, L.C. (1987). Effect of fertilizer factory effluent on soil and crop productivity. Water, Air and Soil Pollution, 33: 309-320.

[27] Truman, R.A., Humphreys, F.R., Ryan, P.I. (1986). Effect of varying solution ratios of aluminium to calcium and magnesium on the uptake of phosphorous by Pinus radiate. Plant Sci. 96: 109-133.

[28] Vaithiyanathan, T., Soundari, M. and Sundaramoorthy, P. (2014). Response of black gram (vigna mungo L.) to sugar mill effluent treatment. International Journal of Research in Botany. 4(1), 1518.

[29] Verma, A. and Verma, A. P. (1995). Effect of tannery effluent on seed germination and chlorophyll content in Phaseolus radiates L. J. Industrial Pollution Control, 11(1): 63-66.

[30] Vijayaragavan, M.,Prabhahar, C., Sureshkumar, J., Natarajan, A., Vijayarengan, P. and Sharavanan, S. (2011). Soil irrigation effect of sugar mill effluent on changes of growth and biochemical contents of Raphanussativus L. Current Botany, 2(7):09-13. 